\title{
Aspekte van versoening in die boek Genesis
}

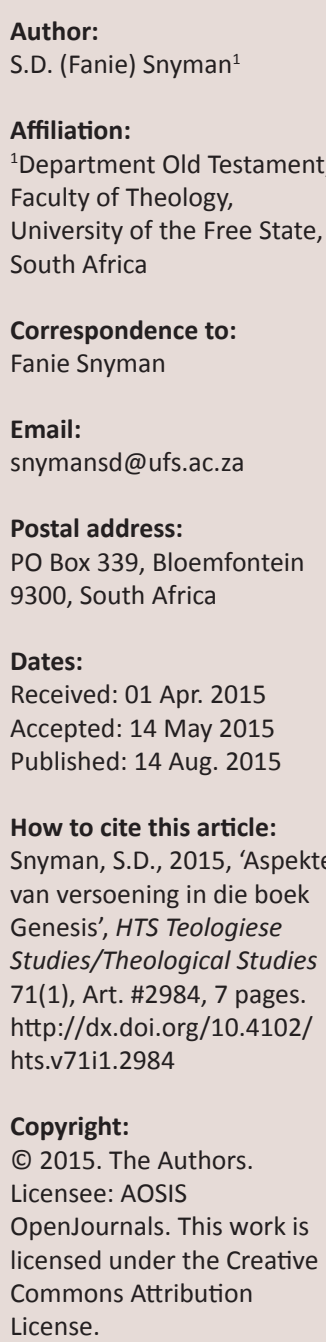

Read online:

Scan this QR
code with your
smart phone or
mobile device
to read online.

Aspects of reconciliation in the book of Genesis. This contribution investigates the notion of reconciliation in the book of Genesis. The problem addressed is how the phenomenon of reconciliation between human beings happens in spite of, or perhaps because of, alienation between people. Research on the topic highlights three episodes in the book, Abraham and Lot (Gn 13), Jacob and Esau (Gn 33), and Joseph and his brothers (Gn 37-50). This contribution adds a fourth episode of reconciliation that is between Jacob and Laban (Gn 31). In the end, a few conclusions are drawn and applied to current society.

\section{Inleiding}

By wyse van inleiding is daar 'n paar opmerkings wat gemaak moet word oor die titel en aanpak van die bydrae. Die titel van die bydrae is Aspekte van versoening in die boek Genesis. Die probleem wat aangespreek word in die artikel is die verskynsel van versoening wat tussen mense gebeur. Versoening tussen mense gebeur omdat daar vervreemding is tussen mense soos wat dit keer op keer verhaal word in die boek Genesis. Die kwalifikasie deur die woord 'aspekte' beteken dat daar 'n voorlopige en noodwendigerwys ook 'n beperkte oorsig aangebied word van die tema van versoening in die boek Genesis. Die fokus van die ondersoek val ook meer op die tweede deel van die boek Genesis (12-50), omdat die saak van versoening in dié gedeelte meer prominent ter sprake kom. 'n Derde opmerking is dat die ondersoek nie bedoel dat versoening die belangrikste tema in die boek Genesis is nie ${ }^{1}$. Genesis is 'n omvattende boek wat uit 'n verskeidenheid van perspektiewe bestudeer word en daarom verteenwoordig die ondersoek slegs ' $n$ beperkte blik op 'n onderbeklemtoonde aspek van die boek ${ }^{2}$. 'n Vierde opmerking oor die tema van versoening: by 'n kongres waar 'vrede' die tema is, is versoening die voorwaarde vir vrede. Vrede is die resultaat van versoening. Daar is ook ander noodsaaklike bestanddele vir 'n proses wat lei tot vrede. Sake soos restitusie, belydenis en vergiffens is sake wat aan die orde behoort te kom. In hierdie bydrae val die klem egter op versoening soos wat dit na vore kom in die boek Genesis.

Die boek Genesis is 'n belangrike en interessante boek in die Ou Testament. Dit is belangrik omdat dit die eerste boek in die Ou Testament/Hebreeuse Bybel is en wat open met 'n universele perspektief op die wêreld deur die verhaal van die skepping te vertel. Vir Brueggemann (2003:29) bied Genesis ' $n$ 'cosmic perspective that constitutes a brief theological history of the world'. Dit bly ' $n$ merkwaardige feit dat die Ou Testament/Hebreeuse Bybel nie begin met'n weergawe van Israel se verblyf in Egipte of by die Sinai gebeure nie, maar met 'n universele perspektief op 'hemel en aarde' soos wat Genesis 1:1 dit stel. Dit is 'n interessante boek omdat die temas wat daarin voorkom al die bestanddele bevat van 'n eietydse TV seep-opera. Genesis vertel verhale oor families, familietwiste, die al te dikwelse probleem van ' $n$ troebel verhouding tussen pa en seun; die wedywering tussen broers wat in een geval selfs tot 'n moordsaak lei (Kain en Abel; Jakob en Esau, Josef en sy broers); mans wat die vrou(e) van hulle drome vind (Isak en Rebekka, Jakob en Lea en Ragel); die huwelikspanning tussen man en vrou (Abraham en Sarai); internasionale diplomatieke skandale met seksuele innuendo's (Gen 12:10-20); die trauma van kinderloosheid by ' $n$ vrou in ' $n$ tyd toe dit van buitengewone belang was vir 'n vrou om kinders in die wêreld te bring; 'n verkragting (Gen 34); 'n man wat verlei word tot 'n seksuele verhouding met 'n getroude vrou maar wat die verleiding weerstaan (Josef en Potifar se vrou in Gen 39); 'n verhaal van 'n skoonpa wat met sy skoondogter seksueel verkeer terwyl hy onder die indruk is dat sy 'n prostituut is (Gen 38); en 'n wonderlike 'rags to riches' verhaal in die Josef narratief (Gen 37-50). Van die ou verhaal van Noag word 'n kontroversiële film gemaak (Noah). Die verhaal van die toring van Babel bly een van die klassieke verhale in Genesis.

1.Die tema is egter al grondig ondersoek in ' $n$ aantal artikels: vergelyk Coats (1980:82-106), Albertz (1990:132-144), Crüsemann (1994:67-77), Thompson (1979:5-26) en Thompson (2011:174-200).

2.Dit is opvallend dat kommentare die saak van versoening noem, maar dit nie as 'n prominente aspek in die teologie van die boek as geheel hanteer nie. In die kommentaar op die relevante teksgedeeltes word die saak van versoening ook genoem maar sonder dat ' $n$ in diepte bespreking daarvan aangebied word. Vergelyk in dié verband Westermann (1986), Moberly (2009), Reno (2010), Waltke en Fredricks (2001) sowel as Von Rad (1981). 


\section{Die Boek Genesis as 'n boek van vervreemding}

Die boek Genesis vertel 'n verhaal van toenemende vervreemding. Vroeg in die boek is daar die insident van 'n ingrypende vervreemding tussen God en die mense (Gen 3). Leder (2011) stel die saak so:

[...] that Adam and Eve's refusal of divine instruction and consequent exile from the garden of Eden and God's presence, defines the narrative problem or deficit which initiates a series of events, complications and conflicts between the Creator and humanity that come to a certain resolution with God's selection of Abraham and the promise of land, progeny and blessing. (p. 24)

Die mislukking van Adam en Eva lei tot vervreemding tussen die eerste mensepaar en God. Hierdie vervreemding tussen God en mense neem tot so mate toe dat God selfs berou het oor sy besluit om mense te skep (Gen 6).

Genesis vertel ook die verhaal van'n groeiende vervreemding tussen mense. Adam is gou om die vrou te blameer: 'Die vrou wat $\mathrm{U}$ my gegee het om my by te staan, sy het vir my van die boom se vrugte gegee en ek het geëet' (Gen 3:12) toe hy deur God uitgevra word oor wat gebeur het in die tuin. Genesis 3:15 se vloek behels vyandskap tussen mense: 'Ek stel vyandskap tussen jou en die vrou, tussen jou nageslag en haar nageslag' (Gen 3:15). 'n Toestand van vyandskap is die presiese teenoorgestelde van versoening. Die eerste gerapporteerde moord is die tussen broer en broer, Kain wat sy broer Abel vermoor (Gen 4:1-16). Lameg se uitroep om wraak en om hom sewe en sewentig keer te wreek, is goed bekend (Gen 4:24) (Thompson 2011:183). Dit is daarom ook nie vreemd om te lees dat God se uiteindelike beoordeling van die wêreld was dat dit korrup en vol geweld was (Gen $6: 11$ ). Na die vloed word die ongelukkige insident vertel wat lei tot Noag se vloek op die nakomelinge van sy seun Gam, wat hulle 'tot 'n nikswerd slaaf in diens van sy broers' verdoem (Gen 9:25) en wat noodwendiger wys lei tot vyandskap tussen die seuns van Noag. Genesis 11:1-9 vertel die verhaal van hoe 'die mense oor die hele aarde verstrooi' (Gen 11:9) word omdat hulle mekaar nie kon verstaan nie.

Hierdie toenemende vervreemding word voortgesit in die tweede deel van Genesis. Abram moet sy land, sy mense en sy familie verlaat (Gen 12:1). Dit is haas onmoontlik om die intensiteit van die vervreemding wat hier beskryf word te onderskat. Abram moet alles agter laat in gehoorsaamheid aan God.

Na Hagar se swangerskap is daar vervreemding tussen haar en Sarai (Gen 16). Hagar minag Sarai (Gen 16:4) en op haar beurt behandel Sarai vir Hagar sleg (Gen 16:6), so veel so dat Hagar besluit om weg te loop van haar af. Die indruk word gewek dat die insident van Hagar se swangerskap ook spanning tussen Abram en Sarai geskep het. Sarai beskuldig vir Abram dat hy die een is wat die onreg teen haar moet verduur (Gen 16:5). Hagar keer terug na Sarai, maar eventueel word Hagar en haar seun Ismael tog weggestuur, waarskynlik as gevolg van die gespanne verhouding tussen Sarai en Hagar (Gen 21:9-10). Vervreemding is iets wat binne die familie van Abram gebeur, ten spyte van die vreugde wat die geboorte van die seun van die belofte ook bring.

Na die insident op die berg Moria in Genesis 22 lyk dit asof daar vervreemding intree tussen Abraham en Isak. Terwyl dit duidelik gestel word dat die vader en seun saam die berg op is en dat hulle in gesprek met mekaar is (Gen 22:7), is daar geen gesprek tussen Abraham en Isak na die gebeure op die berg nie. Genesis 22:19 vertel dat Abraham teruggekeer het na sy slawe toe maar sonder enige vermelding van Isak wat saam met hom terugkeer. Na Genesis 22 word geen gesprek tussen Abraham en Isak weergegee of gerapporteer nie. Dat Abraham sonder Isak terugkeer van die berg nadat die teks dit aanvanklik duidelik maak dat Abraham met twee slawe 'en ook sy seun Isak' (Gen 22:3) na die berg vertrek het, en dat die teks verder vermeld dat 'Ek en die seun gaan daar aanbid' (Gen 22:5) en pa en seun 'so saamloop' (Gen 22:6, 8), maak die vervreemding tussen Abraham en Isak tog waarskynlik. Die verhaal beklemtoon hoe Abraham en Isak saam die tog na Moria aangepak het maar net Abraham word vermeld as hy terugkeer na sy slawe (Gen 22:19). Interessant genoeg word ook geen gesprek tussen God en Abraham gerapporteer na die insident op berg Moria nie (reds. Birch et al. 1999:84).

Die verhaal van die tweeling broers Esau en Jakob is ook 'n verhaal van vervreemding. ' $n$ Aanduiding van die gespanne verhouding tussen die twee broers kry die leser alreeds voor die geboorte van die tweeling wanneer die Here aan Rebekka, die moeder van die twee, sê: 'Daar is twee nasies in jou, twee volke uit jou sal van mekaar geskei word. Een sal sterker wees as die ander, die oudste sal die jongste dien' (Gen 25:23) (Thompson 1979:5-26). Jakob verkry die seën van die eersgeboortereg en verkul sy vader om die seën te verkry. Hierdie gebeurtenis lei tot 'n vervreemding tussen die twee broers, so veel so dat Jakob verplig was om te vlug omdat Esau sy broer gehaat het (Gen 27:41). Was daar ook vervreemding tussen Isak en Jakob? Genesis 25:28 sê dat Isak vir Esau voorgetrek het en in Genesis 27:35 is dit Isak wat Jakob beskuldig dat hy hom bedrieg het en sodoende Esau se seën van hom weg geneem het.

Tussen Jakob se twee vroue Ragel en Lea was daar ook vervreemding (Wenham 1994:345). In Genesis 30:1 word gesê dat Ragel jaloers geword het op Lea omdat sy nie kinders in die wêreld kon bring nie. Die res van Genesis 30 is eintlik 'n verhaal van die wedywering tussen twee vroue om die guns van die man met wie hulle getroud was. Die vervreemding tussen Ragel en Lea herinner aan die vervreemding tussen Sara en Hagar vroeër in die verhaal.

Daar is ook vervreemding tussen Jakob en sy skoonpa Laban. In Genesis 31:2 word gesê: 'Jakob het ook aan Laban gemerk dat hy nie meer soos voorheen oor hom voel nie'. Die vroue van Jakob het die kant van hulle man gekies en op die manier het daar ook vervreemding ingetree tussen Laban 
en sy dogters. As Jakob dan wegtrek van Laban af, doen hy dit sonder om vir Laban in kennis te stel en die optrede het die vervreemding tussen skoonseun en skoonpa verder vererger. In Laban se oë was Jakob 'n bedrieër (Gen 31:27) en 'n dief (Gen 31:30).

Genesis 34 vertel die verhaal van Dina se verkragting deur Sigem. Hierdie insident was die rede vir vervreemding tussen die Hewiete, en Jakob en sy familie, ten spyte van pogings om verhoudings te herstel na die verkragting van Dina.

Genesis 37-50 bevat die verhaal van Josef en sy broers. Josef word uitgebeeld as 'n arrogante, bedorwe lieflingseun van sy pa. Begryplikerwys is sy broers jaloers op hom, selfs tot op die punt waar hulle ' $n$ plan beraam en uitvoer om ontslae te raak van hom. Genesis 37:4 sê dit in soveel woorde dat Josef die geliefde seun van sy pa was en dat sy broers hom om die rede gehaat het. Selfs al het die broers besef Josef 'is ons broer, hy is bloedfamilie' (Gen 37:27) besluit hulle om hom aan Midianitiese handelaars te verkoop. Genesis 37 vertel die verhaal van vervreemding tussen broers. Leder (2011:61) karakteriseer die 'plot' van die boek Genesis as vier groot konflikte wat deels opgelos word in die Josefsverhaal.

\section{Vier verhale van versoening}

Tog, ten spytevan al die verhalevan vervreemding, vyandskap en konflik tussen mense is daar ook merkwaardige verhale van versoening. In die navorsing wat gedoen word op die tema van versoening, word die versoening tussen Jakob en Esau aan die een kant en tussen Josef en sy broers aan die anderkant gewoonlik belig as voorbeelde van versoening (Amos 2006:12). Vir Seidl (2013:841-842) is daar drie verhale van konflik in Genesis deur ook die gebeure tussen Abram en Lot in Genesis 13 by te voeg by die van Jakob en Esau en Josef en sy broers, onderskeidelik. Vir Seidl word die verhale vertel om aan te toon hoe konflik opgelos kan word en kan dien as modelle vir morele standaarde vir Israel om op die regte manier met mense oor die weg te kom. In hierdie bydrae word ' $n$ vierde verhaal van versoening bygevoeg. Ten spyte van die vervreemding tussen Jakob en sy skoonpa Laban in Genesis 30 kom hulle tog tot versoening in Genesis 31:19-35 waar ' $n$ dreigende konflik afgeweer word en skoonpa en skoonseun vredevol uit mekaar gaan.

\section{Abram en Lot in Genesis 13}

Genesis 13 is 'n verhaal van konflik oor voldoende lewensruimte vir mense wat dig by mekaar leef (Westermann 1985:174). Lot het saam met Abram getrek toe hy van Egipte af na die Negev en vandaar na Betel getrek het. Alhoewel dit nie in soveel woorde gesê word nie, het Abram aan Lot gedink as die vervulling van die belofte van 'n nageslag aan hom. In Genesis 13 ontwikkel daar 'n situasie waar die veewagters van Abram en Lot in 'n twis met mekaar gewikkel raak oor voldoende weiding vir hulle diere. Genesis 13:6 som die probleem op as volg: 'Die land kon nie in Abram en Lot se behoeftes voorsien sodat hulle bymekaar kon bly nie'. Von Rad (1981:171) het opgemerk dat die probleem van 'n groeiende kudde vir beide
Abram en Lot nie moeilik is om te verstaan nie. ' $\mathrm{n}$ Kudde diere het ' $n$ beduidende stuk grond nodig vir weiding asook 'n voldoende bron van genoeg water wat bes moontlik skaars kommoditeite was in die omgewing. Die konflik ontstaan dus as gevolg van die seën van die Here. Abram bedink toe 'n plan wat daarop neerkom dat hy en Lot elkeen 'n stuk van die beskikbare grond kies en wat dus die gevolg sal hê dat hulle weë noodwendiger wys sal skei. Abram tree in die uitvoering van die plan ruimhartig op deur vir Lot die eerste keuse te gee van watter deel van die beskikbare grond hy sou wou okkupeer. Lot kies die klaarblyklike beter deel van die grond en ten spyte hiervan maak Abram geen beswaar teen die keuse wat Lot gemaak het nie. Op die manier word daar geslaag daarin om 'n potensieel plofbare situasie vreedsaam tot 'n oplossing te bring, sonder dat hulle verhouding versleg (McKeown 2008:84). Abram word in die beste moontlike lig geteken en volgens Von Rad (1981:171) doen die verteller dit doelbewus so om Abram as 'n navolgenswaardige voorbeeld te laat dien. Op hierdie manier dien Abram as die ouer en daarom ook meerdere persoon, as 'n goeie voorbeeld van hoe om konflik op 'n vredevolle manier te besleg (Reno 2010:149; Waltke \& Fredricks 2001:221). Teen 'n breër agtergrond beskou, dien die teks moontlik ook as 'n vermaning aan Israel om hulle bure, die Moabiete en die Amoriete, met respek te behandel juis omdat daar familiebande ter sprake is wat ver in die verlede teruggryp (Seidl 2013:845).

Toe konflik die verhouding tussen Abram en Lot bedreig, was versoening die oplossing selfs as dit sou beteken dat die uiteindelike uitkoms nie noodwendig die beste of die mees regverdige oplossing was nie. Die twis en onmin tussen twee familiegroepe word vreedsaam besleg deur uit mekaar te gaan (Westermann 1985:177). Versoening vind plaas deur middel van 'n onderhandelde ooreenkoms selfs al het alles nie regverdig verloop vir al die partye betrokke nie. Die belangrike resultaat was vrede eerder as die voortsetting van konflik. Later in die boek hou die versoening tussen Abram en Lot steeds stand wanneer Abram ter wille van die behoud van Lot en sy familie intree by God om hulle te red van die oordeel oor Sodom en Gomorra. Abram se optrede word gemotiveer deur sy vertroue in God en in die belofte wat God aan hom gemaak het (Brueggemann 1982:131).

\section{Laban en Jakob in Genesis 31}

Die verhouding tussen Laban en Jakob begin in Genesis 29. Beide Laban en Jakob is in 'n oor en weer kullery met mekaar betrokke. Aanvanklik is dit Laban wat vir Jakob verkul met sy dogters wat Jakob se vroue word. Later is dit weer Laban wat vir Jakob bedrieg met 'n slenter om Jakob uit die aanteel van vee te kul (Gen 30:25-36). Jakob uitoorlê egter vir Laban op die punt (Gen 30:37-43) en so word 'n situasie van 'n oor en weer kullery geskep (reds. Birch et al. 1999:88-89). Brueggemann (1982:251) karakteriseer die hele verhaal wat hom afspeel tussen Laban en Jakob as een van konflik.

In Genesis 31 word vertel hoe dat die verhouding tussen Jakob en sy skoonpa stelselmatig verswak het. Volgens Jakob 
het Laban hom nie goed behandel nie deur lone wat nie regmatig aan hom betaal is nie selfs ten spyte van Jakob se harde werk oor baie jare in diens van Laban. Jakob se vroue ondersteun hom in die saak, en versterk deur 'n visioen van God om terug te keer na sy land toe, besluit hy om van Laban af weg te vlug.

Drie dae nadat Jakob gevlug het, agtervolg Laban hom en haal hom eventueel in. Met hulle ontmoeting beskuldig Laban vir Jakob dat hy hom bedrieg het (Gen 31:26-27). Selfs belangriker nog, Jakob word ook daarvan beskuldig dat hy die sogenaamde huisgode gesteel het. Laban slaag nie daarin om die huisgode te vind nie, al was sy dogter Ragel die een wat die diefstal gepleeg het en wat die huisgode weggesteek het toe hy daarna gesoek het. Jakob besluit om die geleentheid tot sy eie voordeel te benut en in ' $n$ heftige argument waarin hy kwaad word, neem hy sy saak met Laban op. Jakob se argument is duidelik: hy wat Jakob is, sou na twintig jaar se harde werk niks kon wys nie omdat Laban hom so sleg en onbillik behandel het. Westermann (1985:497) wys daarop dat die beskuldiging neerkom op 'n ernstige oortreding van die verbondsbepalings, immers, 'n werknemer was geregtig op ' $n$ billike loon vir dienste gelewer.

Laban besef dat dit ' $n$ argument is wat hy gaan verloor en hy stel 'n verbondsluiting voor tussen hom en Jakob. Jakob op sy beurt aanvaar die aanbod van Laban en so word 'n potensieel fisiese konflik afgeweer toe beide partye deel word van die verbondsluiting. Wat tussen Jakob en Laban (sy oom en skoonpa) gebeur is niks minder as 'n handeling van versoening nie. Die resultaat van die versoening is vrede, gesimboliseer deur die gemeenskaplike maaltyd wat die twee saam nuttig (Gen 31:54).

Laban is eintlik die een wat onregverdig behandel is in die verhouding. Laban was reg dat Jakob hom bedrieg het en hy was ook reg dat Jakob se huishouding verantwoordelik was vir die diefstal van die huisgode. Jakob is egter die een wat seevier in die argument wat gevoer is. Die resultaat hiervan is dat Laban, wat eintlik die slagoffer was van Jakob, se bedrieglike handelinge, die inisiatief moes neem om tot versoening te kom met sy skoonseun. Westermann (1985) maak die volgende opmerking aan die einde van sy uitleg van die hoofstuk:

The well-being of a community always includes the possibility of the settlement of a dispute as long as the will for peace remains; this is expressed in Gen 31 by the common meal. (p. 500)

\section{Jakob en Esau in Genesis 33}

Die geskiedenis van die tweelingbroers Jakob en Esau is 'n gekompliseerde en hartseer geskiedenis. Die twee broers was 'n tweeling, maar daar was groot verskille tussen hulle in terme van persoonlikheid ${ }^{3}$. Esau was die jagter, die een wat die buitelewe geniet het. Jakob was die een wat eerder tuis gebly het. Om sake verder te kompliseer, was elkeen van die tweeling 'n gunsteling van 'n ouer. Volgens Genesis 25:28 het Isak vir Esau liefgehad, terwyl Rebekka weer vir Jakob liefgehad het. Jakob het aanvanklik sy broer bedrieg uit sy eersgeboortereg en later het hy ook die seën van Isak, wat vir Esau bedoel was gesteel (Gen 25:29-34; 27:1-40). Die resultaat hiervan was dat Esau 'n wrok teen sy broer gekoester het, selfs tot op die punt waar hy beplan het om sy broer om die lewe te bring (Gen 27:41). Jakob het dus geen ander keuse gehad nie as om te vlug van Esau na die broer van sy ma Laban. Volgens Genesis 33 blyk dit asof Esau nog steeds kwaad is vir sy broer want hy nader Jakob met 'n leër van 400 man.

Toe gebeur die ondenkbare. Die twee broers versoen. Uit hulle gemeenskaplike verlede is dit duidelik dat Jakob die skuldige een is in die verhaal. In Genesis 33 is hy op weg terug om Esau te ontmoet. Die terugkeer van Jakob is moontlik slegs deur versoening (Westermann 1985:523). Jakob nader vir Esau op 'n manier wat as versigtig beskryf kan word. Jakob waag die risiko omdat dit ook 'n geleentheid tot versoening is (McKeown 2008:156). Hy is duidelik bewus van Esau se wraakgedagtes en dat hy wat Jakob is eintlik die skuldige party in die verhouding is (Brueggemann 1982:262). Wanneer hy eventueel vir Esau persoonlik ontmoet, buig hy sewe keer voor hom, 'n gebaar wat net vir koninklikes gereserveer was (Seidl 2013:852; Van Selms 1967:146; Von Rad 1981:327; Westermann 1985:524). Op 'n ironiese manier word die seën van Isak (Gen 27:29) - 'Volke sal jou dien, nasies sal voor jou buig; oor jou familie sal jy heers, jou broers sal voor jou buig' - omgekeer wanneer dit Jakob is wat buig voor Esau. Nie minder nie as drie keer stel Jakob dit duidelik dat dit sy bedoeling is om genade in die oë van Esau te vind (Gen 33:8, 10, 15). McKeown (2008:157) merk in die verband op dat die taalgebruik nie dié is van broederlike liefde of toegeneentheid nie, maar eerder dié van diplomatieke terminologie van iemand wat genade en versoening soek. Dit is die merkwaardige aksent in hierdie verhaal van versoening: dit is die een wat skuldig is, die een wat verantwoordelik is vir onmin en afstand wat versoening inisieer. Die reaksie van Esau is ewe merkwaardig en in kontras met die groet van Jakob. Hy antwoord nie met aanklagte, beskuldigings, wraak en die aandrang op vergelding nie. Die teks vertel hoe Esau sy broer tegemoet hardloop, sy arms om hom werp, hom omhels en soen, en dan huil die broers saam. Esau dring nie aan op vergoeding vir die skade wat hy as gevolg van Jakob gelei het nie. Esau se reaksie is eerder een van vergiffenis as een van vergelding. Jakob bied vir Esau 'n geskenk aan. Die woord wat gebruik word is interessant want die geskenk wat Jakob aanbied is brk (ברך), die Hebreeuse woord wat gewoonlik vertaal word met seën (Leder 2011:73). Jakob bied vir Esau seën aan, presies dit wat hy van Esau gesteel het! Esau wys die geskenk aanvanklik af, maar aanvaar dit tog as 'n gebaar van welwillendheid. Die geskenk wat Jakob aanbied funksioneer dus op 'n manier as 'n daad van restitusie (Westermann 1985:530) en daarmee word die versoening tussen die broers verseël (Waltke \& Fredericks 2001:455). Terwyl Jakob vir Esau aanspreek as 'my heer' (Gen 33:8) en homself as 'n slaaf van Esau beskou (Gen 33:14) - die 
soort van taal wat 'n vasaal teenoor sy meerdere sal gebruik antwoord Esau deur vir Jakob aan te spreek as 'my broer' (Gen 33:9) (Agyenta 2007:124-125; Seidl 2013:851). Die afstand wat die tweelingbroers van mekaar geskei het, is oorbrug en versoening word 'n werklikheid. Esau se plan om vir Jakob om die lewe te bring is nou iets van die verlede en daar is geen bedreiging van geweld tussen die broers nie (Agyenta 2007:131). Die verhaal begin met die moontlikheid van oorlog en bloedvergieting. Esau nader immers vir Jakob met ' $n$ leër van 400 man, gereed om die dade van die verlede te wreek. Die verhaal toon egter dat versoening 'n beter opsie as bloedvergieting is. In Genesis 35:29 staan daar dat Esau en Jakob hulle pa begrawe het-'n aanduiding dat die versoening wat in Genesis 33 vertel word, durend van aard was.

Soms is daar net 'n klein tree nodig wat die deur na versoening oopmaak. In hierdie geval was dit Jakob wat sy broer nader en voor hom buig. 'n Handeling van versoening bly egter 'n risiko. Brueggemann (1982:263) tipeer die verhaal van Genesis 33 as die 'risky way to reconciliation'. Jakob neem die risiko om sy lewe en die lewe van sy geliefdes op die spel te plaas. Dit word duidelik as 'n mens let op die sorgvuldige voorbereiding wat Jakob tref. Sy geliefdes word in drie verskillende groepe verdeel met die bedoeling dat minstens sommige 'n aanval van Esau sal oorleef sou hierdie inisiatief van hom misluk (Gen 33:1). Die uitkoms van die verhaal toon dat die risiko wat hy geneem het tog die moeite werd was.

Versoening is broos. Versoening is dikwels onvolledig en onvolmaak. Jakob en Esau kom tot versoening, en tog besluit hulle om nie saam te bly nie maar dat elkeen liewers sy eie weg gaan. Esau kies koers na Seir en Jakob vertrek na Sukkot (Gen 33:16). Dit lyk asof Jakob ten spyte van die versoening dit tog moeilik vind om vir Esau te vertrou in die hernude verhouding. Versoening is dus nie 'n doel in sigself nie, dit is eerder 'n nuwe begin. Agyenta toon aan dat die skeiding van die weë tussen Jakob en Esau nie negatief verstaan hoef te word nie: '... reconciliation is a matter of attitudinal change, especially, a change from the desire to eliminate or dispossess each other to mutual respect and collaboration between former rivals' (Agyenta 2007:132).

\section{Josef en sy broers in Genesis $\mathbf{5 0}$}

Dit is vir lank reeds 'n uitgangspunt in die interpretasie van die Josef verhaal dat alhoewel die verhaal 'n tipiese verhaal is, dit tog ook ooreenkomste vertoon met Israel se wysheidliteratuur soos byvoorbeeld Job en Spreuke (reds. Birch et al. 1999:92; De Fraine 1963:261; Loader 1987:103). Die versoening wat plaasvind tussen Josef en sy broers is naas die Jakob-Esau versoening in Genesis 33 die mees opvallende en prominente verhaal van versoening in Genesis. Dit is dus ook te begrype dat die verhaal getipeer word as 'n verhaal van vervreemding en verdoening (reds. Birch et al. 1999:93).

Die versoening tussen Josef en sy broers word vertel in twee episodes. In Genesis 45 'kon Josef homself nie langer bedwing nie' (Gen 45:1) en het hy sy identiteit aan sy broers bekend gemaak. Wat merkwaardig is in die verhaal is dat
Josef nie vergelding eis nie, maar versoening aanbied. Josef het alle rede gehad om sy broers nie te vergewe nie (Kim 2013:236), immers, 'Julle het my verkoop en ek is Egipte toe gebring' (Gen 45:4). Josef se versoening met sy broers het nie beteken dat hy die geskiedenis vergeet het nie. Nie menslike skuld nie, maar God se hand was toe al die tyd aan die werk in wat met hom (Josef) gebeur het. Dit was nie die broers wat Josef in Egipte laat beland het nie, maar God (Gen 45:8). Op 'n wyse wat 'n misterie bly, staan God se handelinge tog in verband met dit wat sy broers hom aangedoen het (Von Rad 1981:398). Die resultaat van versoening is die herstel van verhoudings, in die geval van Josef word sy verhouding met sy broers herstel ongeag en selfs ten spyte van die onreg van die verlede (Berthoud 2008:9-10). Die een wat verontreg is, is die een wat versoen met diegene wat hom verontreg het.

Die tweede episode van versoening word aan die einde van Genesis vertel. Na Jakob se dood was Josef se broers onseker of Josef hom nie nou gaan wreek op sy broers nie. Dit is Josef wat die merkwaardige woorde in Genesis 50:20 uiter: 'Julle wou my kwaad aandoen, maar God wou daarmee goed doen: Hy het gesorg dat 'n groot volk nou in die lewe gebly het'. Leder (2011:76) merk na aanleiding van die teks op: 'Joseph's acknowledgment of God's action in his misery and rise to power in Egypt reconciles the older and the younger'. Wat tussen Josef en sy broers gebeur is in 'n sekere sin die teenpool van die Kain en Abel verhaal. In plaas daarvan dat dit 'n ouer broer is wat die jonger een om die lewe bring, is dit die jonger broer wat hom versoen met die ouer broers, met die resultaat dat almal bly lewe. In die geval van Josef is dit duidelik dat hy die slagoffer is van onreg wat sy broers hom aangedoen het. Josef is egter die een wat versoening soek met die persone wat hom onregverdig behandel het. In plaas van konflik en wraak tussen die broers (stamme van Israel) moet hulle eerder vir mekaar sorg dra en ondersteun (Seidl 2013:859). As in gedagte gehou word dat die Josef verhaal as wysheidsliteratuur beskou word, is die boodskap duidelik: dit is wys om tot versoening te kom selfs in 'n situasie war jy die een is wat die slagoffer is van ongeregtigheid en onregverdige behandeling.

\section{Gevolgtrekking}

By wyse van 'n slot word 'n aantal gevolgtrekkings gemaak uit die voorlopige ondersoek, saam met ' $n$ aantal toepassings na die praktyk van versoening.

Versoening is deur en deur ' $n$ teologiese konsep. In die boek Genesis het versoening te doen met die verhouding tussen God en mens. Die verbond wat Jakob en Laban met mekaar sluit word gesluit deur die aanroep van die God van Abraham en Nahor (Gen 31:53) om tussen hulle te oordeel. Jakob sweer ' $n$ eed in die naam van die Skrik van Isak sy vader waartydens daar offers gebring word (Gen 31:54). Jakob se ontmoeting met Esau word voorafgegaan deur die ontmoeting wat Jakob gehad het met die misterieuse figuur van Genesis 32, waarskynlik 'n manifestasie van Jahwe. Dit is in hierdie verband wat Brueggemann (1982:272) opmerk: 'The meeting with God and the meeting with the brother run together 
in the experience with Jacob'. Daar is ' $n$ bepaalde verwantskap tussen Jakob se ontmoeting in Genesis 32 en sy ontmoeting met Esau in Genesis 33 (Amos 2006:20). Josef beskou sy lewe in Egipte as in verhouding met God. Terwyl dit sy broers was wat verantwoordelik was vir alles wat hy moes verduur, was God tog aan die werk in dit alles. Dit was God wat hom 'n heerser oor die hele Egipte gemaak het (Gen 45:9). Later in Genesis is dit Josef wat sê: 'Julle wou my kwaad aandoen, maar God wou daarmee goed doen ...' (Gen 50:20). As die begrip versoening as ' $n$ teologiese begrip hanteer word, kan versoening nooit 'n goedkoop en oppervlakkige onderneming wees nie.

Menslike verhoudings neig om mense van mekaar te vervreem eerder as om mense te verenig. Menseverhoudings loop skeef juis waar naby, intieme verhoudings tussen mense bestaan. Versoening vind dus plaas in ' $n$ atmosfeer van vervreemding. Versoening vind plaas waar daar stryd, konflik, ongeregtigheid, geweld en verslegtende menseverhoudings is. Versoening is dus nooit maklik om te verwerklik nie.

Versoening gebeur dikwels op 'n baie persoonlike manier tussen mense. Dit is opvallend dat die gevalle van versoening tussen mense in die boek Genesis is mense wat in ' $n$ familieverhouding met mekaar staan, wat in konflik met mekaar is en dan moet versoen. Dit is dikwels juis in die intieme sfeer van familieverhoudings waar versoening die noodsaaklikste is. In Genesis word die individue ook korporatiewe persoonlikhede wat nasies of groepe van persone aandui. Versoening het dus aan die een kant die persoonlike kant, maar tegelykertyd ook 'n openbare, publieke dimensie waar die appèl is op groepe om tot versoening te kom.

Die inisiatief vir versoening lê soms by die een wat die oorsaak is van die vervreemding en afstand tussen mense, soos in die geval van Jakob wat versoening soek met sy broer Esau. Soms lê die inisiatief vir versoening by die slagoffer van uitbuiting, geweld en ongeregtigheid. Laban se ontmoeting met Jakob in Genesis 31 dien as voorbeeld hier. Laban is die een wat gely het onder die misleiding van Jakob, omdat Jakob hom oor 'n periode van meer as twintig jaar bedrieg het. Tog is dit Laban wat besef dit is beter om die vyandelikheid te staak en in 'n verbondsverhouding met Jakob te tree wat vrede eerder as voordurende konflik en vyandskap. Die tweede voorbeeld, by uitnemendheid, is Josef. Hy is die een wat onverdiend vervreemding van sy familie moes verduur, die skade en skaamte van vernedering in ' $n$ vreemde land, en wat dan tog kies om nie wraak te neem nie, maar om eerder die weg van versoening met sy broers te stap.

Versoening beteken moeite en opoffering van die een wat 'n versteurde verhouding weer wil herstel. Terselfdertyd dring die een wat die slagoffer is van ongeregtigheid nie aan op volledige kompensasie nie. Die aspek van versoening word veral gesien in beide die Abram-Lot verhaal sowel as die Jakob-Esau verhaal. Abram is tevrede om die minder goeie deel van die land te neem en Esau weier 'n volledige kompensasie aan hom.
Versoening is broos en moet daarom met omsigtigheid en sensitiwiteit hanteer word. Versoening is daarom nie 'n doel op sigself nie, dit is eerder ' $n$ nuwe begin. Versoening wat bereik is, skep nie ' $n$ utopia waar alles verander het na 'n toestand van maanskyn en rose toe nie. In die geval van Abraham en Lot was die beste manier om tot 'n vredevolle oplossing te kom juis die skeiding van weë. Die versoening tussen Jakob en Esau in Genesis 33 was ook nie die perfekte versoening nie. Versoening in hulle geval het ook die skeiding van weë beteken. Dit behoort ook nie as negatief ervaar te word nie. Versoening het ook die element van 'laat gaan' anders sou dit ook nie egte versoening gewees het nie.

Versoening is dus beide ' $n$ gawe en 'n opdrag. Dit is ' $n$ gawe wat God aan mense skenk waardeur hulle in staat gestel word om twis en stryd te oorkom en in vrede met mekaar te lewe. Dit is ook 'n taak wat nie maklik is nie en word met moeite suksesvol uitgevoer.

Versoening is ook 'n voorwaarde vir vrede. Vrede kan nie herstel word voordat strydende partye nie tot versoening gekom het nie. Eers dan kan vrede die uiteindelike resultaat van egte versoening wees.

Versoening is ' $n$ aktuele tema in Suid-Afrika. Tans is daar sprake van 'n toenemende verwydering tussen mense. Op kerklike gebied is versoening ook tot 'n mate nog 'n onbereikbare ideaal. Insigte uit die Bybel kan help om die soeke na versoening 'n groter werklikheid te maak.

\section{Erkenning Mededingende belange}

Die outeur verklaar dat hy geen finansiële of persoonlike verbintenis het met enige party wat hom nadelig kon beïnvloed in die skryf van hierdie artikel.

\section{Literatuurverwysings}

Agyenta, A., 2007, 'When reconciliation means more than the "re-membering" of former enemies: The problem of the conclusion to the Jacob-Esau story from a narrative perspective (Gen 33, 1-17)', Ephemerides Theologicae Lovanienses 83, 123-134. http://dx.doi.org/10.2143/ETL.83.1.2021744

Albertz, R., 1990, 'Die Kleinen Schritte zur Versöhnung Wagen: Streit und Versöhnung in den Jakob-Esau Erzählungen (Gen 25-35)', in R. Albertz (Hrsg.), Der Mensch als Hüter seiner Welt: Alttestamentliche Bibelarbeiten zu den Themen des konziliaren Prozesses, pp. 132-144, Calwer, Stuttgart.

Amos, C., 2006, 'The Genesis of reconciliation: The reconciliation of Genesis', Mission Studies 23(1), 12-20. http://dx.doi.org/10.1163/157338306777890466

Berthoud, P., 2008, 'The reconciliation of Joseph with his brothers. Gen 45.1-11 (42.1-45.11) and 50.15-21', European Journal of Theology 17(1), 5-11.

Birch, C., Brueggemann, W., Fretheim, T.E. \& Petersen, D.L. (eds.), 1999, A theological introduction to the Old Testament, Abingdon, Nashville, TN.

Brueggemann, W., 1982, Genesis, Interpretation Series, John Knox, Atlanta, GA.

Brueggemann, W., 2003, An introduction to the Old Testament: The Canon and Christian imagination, Westminster John Knox, Louisville, KY.

Coats, G.W., 1980, 'Strife without reconciliation: A narrative theme in the Jacob tradition', in R. Albertz, H.P. Müller \& H.W. Wolf (Hrsgs.), Werden und Werken des Alten Testament, Festschrift C. Westermann, pp. 82-106, Neukirchener, Neukirchen-Vluyn.

Crüsemann, F., 1994, 'Dominium, guilt and reconciliation: The contribution of the Jacob narrative in Genesis to political ethics', Semeia 66, 67-77.

De Fraine, J., 1963, Genesis, J.J. Romen \& Zonen Uitgevers, Roermond.

Kim, H.C.P., 2013, 'Reading the Joseph story as a Diaspora narrative', Catholic Biblical Quarterly 75, 219-238.

Leder, A.C., 2011, Waiting for the Land. The storyline of the Pentateuch, P \& R, Philipsburg, MT. 
Loader, J.A. 1987, Die verhaal van Josef, in H.L. Bosman, J.A. Loader, F.E. Deist \& P.J. van Dyk (reds.), Vertellers van die Ou Testament, bl. 100-107, Tafelberg Uitgewers, Kaapstad.

McKeown, J., 2008, Genesis: The two horizons Old Testament commentary, William B. Eerdmans Publishing Company, Grand Rapids, MI.

Moberly, R.W.L., 2009, The theology of the book of Genesis: Old Testament theology, Cambridge University Press, Cambridge. http://dx.doi.org/10.1017/ CB09780511626937

Reno, R.R., 2010, Genesis: Brazos theological commentary on the Bible, Brazos, Grand Rapids, MI.

Seidl, T., 2013, 'Conflict and conflict resolution: Inner controversies and tensions as places of Israel's self-conception in the patriarchal traditions of Genesis', Old Testament Essays 26(3), 841-842.
Thompson, T.L., 1979, 'Conflict themes in the Jacob narratives', Semeia 15, 5-26. http://dx.doi.org/10.1080/09018328.2011.608540

Thompson, T.L., 2011, 'Memories of Esau and narrative reiteration. Themes of conflict and reconciliation', Scandinavian Journal of the Old Testament 25(2), 174-200.

Van Selms, A., 1967, Genesis deel II: Prediking van het Oude Testament, Callenbach, Nijkerk.

Von Rad, G., 1981, Genesis, Old Testament Library, SCM, London.

Waltke, B.K. \& Fredricks, C.J., 2001, Genesis: A commentary, Zondervan, Grand Rapid. MI. Wenham, G.J., 1994, Genesis 16-50, Word Biblical Commentary, Word, Waco, TX.

Westermann, C., 1985, Genesis 12-36: A commentary, Augsburg, Minneapolis, MN. Westermann, C., 1986, Genesis 37-50: A commentary, Augsburg, Minneapolis, MN. 